\title{
Control of Bolting in Autumn-sown Sweet Onions through Undercutting
}

\author{
Douglas C. Sanders and Jennifer D. Cure \\ Department of Horticultural Science, North Carolina State Univeristy, Box 7609, Raleigh, NC27695-7609
}

Additional key words. Allium cepa, flowering

\begin{abstract}
The efficacy of undercutting as a technique to control bolting of two short-day onion cultivars was studied in controlled-environment chambers. 'Buffalo' and 'Granex 33' onions were grown to the third, fifth, and seventh visible leaf stages in a 10-hour photoperiod at $22 / 18{ }^{\circ} \mathrm{C}$ (day/night) and then exposed to $30,40,50,60$, or 70 days of vernalizing temperatures $\left(10 / 10{ }^{\circ} \mathrm{C}\right)$. Half of the plants were undercut at the initiation of the vernalizing treatment. After vernalizing treatments, plants were returned to 14 -hour photoperiods at $22 / 18{ }^{\circ} \mathrm{C}$. 'Buffalo', which is resistant to bolting, did not flower significantly under any of these conditions. The flowering response of 'Granex 33 ' increased with leaf number at vernalization and as the duration of vernalization increased. Undercutting ' Granex 33' increased the days of vernalization required for flowering and reduced the proportion of flowering relative to controls. Overall dry-matter accumulation was unaffected by leaf number at vernalization or the duration of vernalization but was reduced $\approx 30 \%$ by undercutting. In both cultivars, fresh mass per bulb decreased with increasing leaf stage of vernalization and number of vernalizing days. Undercutting also decreased fresh mass per bulb, but through its effect on bolting, undercutting increased marketable yield for plants vernalized and undercut at the fifth and seventh leaf stages.
\end{abstract}

Autumn-planted, overwintered onions have the potential to be grown in the southeastern United States. Direct-seeding of sweet onions can produce a savings from $\$ 250$ to $\$ 400$ per acre in production costs over transplanting in the spring. However, certain aspects of the flowering responses of onions in this region must be better understood for this strategy to work well.

It is advantageous to seed onions early because larger plants have higher yield potential and are more winter hardy (Brewster, 1994). However, if fall conditions are very warm, the plants will become too large and increasingly sensitive to low, vernalizing, winter temperatures, which results in spring bolting instead of bulb production (Corgan and Kedar, 1990). The flowering responses of long-day onion cultivars have been thoroughly investigated and modelled. Susceptibility to vernalization has been related to leaf number, which in turn can be predicted on the basis of accumulated degree-days (Brewster, 1987). To our knowledge, no work of this type has been done for short-day cultivars appropriate for the latitudes and temperatures of the southeastern United States.

Currently, there are no short-day sweet onion cultivars that are resistant to bolting. In the field, the practice of plant undercutting has reduced the tendency of autumn-sown onions to bolt (D.C.S., unpublished observation). In years when increased sensitivity to vernalizing temperatures is predicted based on higher than normal temperature and large plant size, undercutting might be used to reduce spring bolting.

In our study, 'Granex 33' and 'Buffalo' onions with different leaf numbers were exposed to vernalizing treatments of different durations, and the effects of undercutting on plant growth, flowering, and yield were evaluated. These short-day cultivars were chosen because 'Granex 33', while sweet, is susceptible to bolting and 'Buffalo' is resistant under regional conditions.

Received for publication 10 Jan. 1996. Accepted for publication 11 July 1996. We acknowledge Cavell Brownie for her statistical advice. The cost of publishing this paper was defrayed in part by the payment of page charges. Under postal regulations, this paper therefore must be hereby marked advertisement solely to indicate this fact.

\section{Materials and Methods}

Our study was conducted in plant growth chambers at the Southeastern Plant Environment Laboratory (Downs and Thomas, 1991). The experimental design was a split-split plot. Main plot factors were the plant stage (leaf number) at which vernalization began (three, five, or seven visible true leaves; see Table 1) and vernalization duration $\left(30,40,50,60\right.$, or $70 \mathrm{~d}$ at $\left.10^{\circ} \mathrm{C}\right)$. There were 15 main plot treatments. Subplot treatments were undercut or not undercut (control), and the sub-subplot factor was cultivar. There were three replicates of each cultivar-treatment combination. All plants within a replicate were kept together in a single growth chamber except during the vernalization treatments, which required mixing of replicates in the cold chambers. There were three destructive harvests: 1) at beginning of vernalization, 2) at the end of vernalization, and 3) at $180 \mathrm{~d}$ (Fig. 1). The temperature before vernalization was $22 / 18{ }^{\circ} \mathrm{C}$ (day/night) with a 10 -h photoperiod. During the vernalization, temperature was $10 / 10^{\circ} \mathrm{C}$, with a 10 -h photoperiod (Brewster. 1987). Postvernalization conditions were $22 / 18^{\circ} \mathrm{C}$ (day/night), with a 14-h photoperiod with a 3-h interruption in the middle of the dark period with incandescent light to ensure a long-day photoperiod response. Photon flux density was maintained at $600 \pm 60 \mu \mathrm{mol} \cdot \mathrm{m}^{-1} \cdot \mathrm{s}^{-1}$ from fluorescent lamps plus $39 \mu \mathrm{mol} \cdot \mathrm{m}^{-1} \cdot \mathrm{s}^{-1}$ from incandescent lamps. Carbon dioxide concentration was monitored and maintained at $\approx 400 \mu \mathrm{mol} \cdot \mathrm{mol}^{-1}$. During the first $40 \mathrm{~d}$, plants were given a complete nutrient solution (Downs and Thomas, 1991) in the morning and nonleaching quantities of deionized water in the afternoon. After $40 \mathrm{~d}$, the nutrient solution was applied twice daily, with a deionized water leaching before the second nutrient application.

Plants were grown in a 50 peat-lite : 50 sand medium in plywood boxes $(45 \mathrm{~cm}$ square and $25 \mathrm{~cm}$ deep) treated with a plantsafe wood preservative. As the boxes were filled with the medium, a plywood partition was inserted dividing the box in half. The undercutting treatment was administered to plants on one side of the partition only. Plants of each cultivar were planted on each side of the partition, creating four quadrants per box: 'Granex 33' with and without undercutting and 'Buffalo' with and without under- 
Table 1. Length of visible leaves (L1 to L7) and dry mass at the initiation of vernalization treatments at the third-, fifth-, or seventh-leaf stages for 'Buffalo' and 'Granex 33' onion plants.

\begin{tabular}{|c|c|c|c|c|c|c|c|c|}
\hline \multirow{3}{*}{$\begin{array}{l}\text { Leaf } \\
\text { stage } \\
(\mathrm{DAP})^{\mathrm{z}}\end{array}$} & \multicolumn{7}{|c|}{ Length $(\mathrm{cm})$} & \multirow{3}{*}{$\begin{array}{l}\text { Dry mass } \\
\text { (g/plant) }\end{array}$} \\
\hline & \multicolumn{7}{|c|}{ Leaf no. } & \\
\hline & L1 & $\mathrm{L} 2$ & L3 & L4 & L5 & L6 & L7 & \\
\hline \multicolumn{9}{|c|}{ Buffalo } \\
\hline $\begin{array}{l}\text { Third } \\
\text { (33) }\end{array}$ & $23.6^{y} \pm 2.6^{x}$ & $29.9 \pm 3.1$ & $11.8 \pm 3.6$ & --- & --- & --- & --- & $0.086^{\mathrm{w}} \pm 0.017$ \\
\hline $\begin{array}{l}\text { Fifth } \\
(47)\end{array}$ & $24.2 \pm 2.8$ & $36.4 \pm 4.2$ & $39.7 \pm 5.0$ & $30.3 \pm 5.5$ & $14.3+4.7$ & --- & --- & $0.345 \pm 0.060$ \\
\hline $\begin{array}{l}\text { Seventh } \\
\text { (63) }\end{array}$ & --- & --- & $41.5 \pm 5.3$ & $50.0 \pm 6.8$ & $52.9 \pm 8.1$ & $37.5 \pm 9.7$ & $16.3 \pm 7.6$ & $1.008 \pm 0.113$ \\
\hline \multicolumn{9}{|c|}{ Granex 33} \\
\hline $\begin{array}{l}\text { Third } \\
\text { (33) }\end{array}$ & $21.1 \pm 2.1$ & $28.9 \pm 3.0$ & $9.1 \pm 3.0$ & --- & --- & --- & --- & $0.066 \pm 0.012$ \\
\hline $\begin{array}{l}\text { Fifth } \\
(47)\end{array}$ & $21.4 \pm 3.0$ & $33.9 \pm 3.8$ & $35.8+6.5$ & $23.7 \pm 7.9$ & $5.9 \pm 5.2$ & --- & --- & $0.246 \pm 0.047$ \\
\hline $\begin{array}{l}\text { Seventh } \\
(63)\end{array}$ & --- & --- & $39.1 \pm 7.4$ & $48.4 \pm 6.4$ & $47.2 \pm 8.6$ & $24.1 \pm 10.5$ & $6.9 \pm 7.0$ & $0.693 \pm 0.072$ \\
\hline
\end{tabular}

${ }^{\mathrm{z}} \mathrm{DAP}=$ days after planting.

${ }^{\mathrm{y}}$ Leaf length values are means of 15 plants (three replications $\times$ five plants) measured to the nearest $0.5 \mathrm{~cm}$ from the base of the plant.

${ }^{x}$ Error values are SD.

wDry-mass values are means of three replications, the five plants per replication were weighed together.

cutting. Within a side, cultivars were randomly assigned to quadrants. In each quadrant, 20 seeds were planted in each of three rows $1.9 \mathrm{~cm}$ deep and covered with $\approx 1.3 \mathrm{~cm}$ of sand. Plants were thinned in steps to five to six plants per row before the first harvest. Initial plant density was $\approx 317 \mathrm{~m}^{-2}$. Harvesting decreased density to 106 $\mathrm{m}^{-2}$ after the vernalization treatment. Plants were not closely spaced until well into bulbing.

Five plants from each quandrant were sampled at the first two harvests; all remaining plants were sampled at the third harvest. At the first harvest, leaf length was measured to the nearest $0.5 \mathrm{~cm}$. Roots were removed uniformly, and the five plants comprising a sample were combined, dried at $60{ }^{\circ} \mathrm{C}$ for at least $48 \mathrm{~h}$, and weighed. After the sampling, undercutting was performed on the

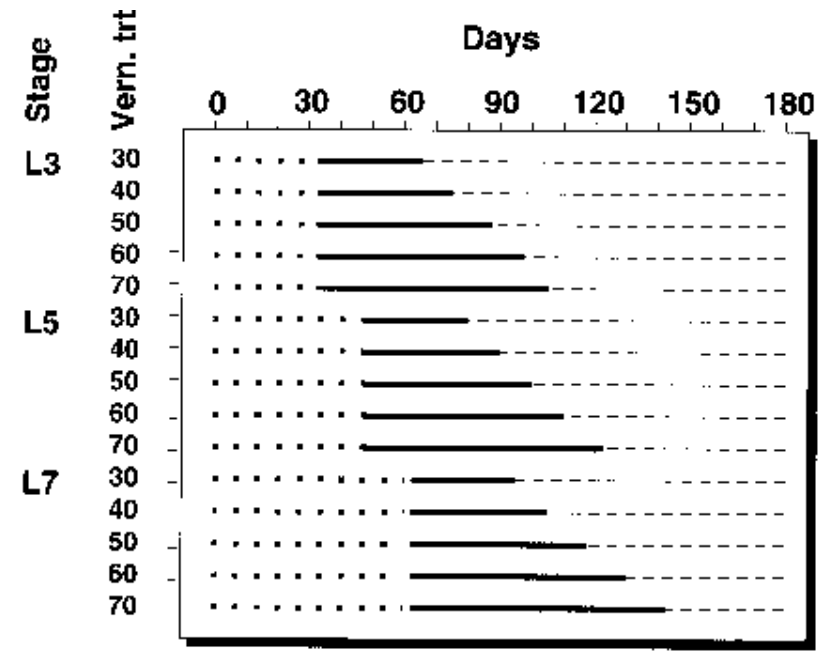

Fig. 1. Experimental design. 'Buffalo' and 'Granex 33' onions were vernalized for varying numbers of days at the third, fifth, or seventh visible leaf stage. Prevernalizing conditions (dotted line): $10 / 14$-h light/dark cycle at $22 / 18{ }^{\circ} \mathrm{C}$. Vernalizing conditions (solid bar): 10/14-h light/dark cycle at $10 / 10{ }^{\circ} \mathrm{C}$. Postvernalizing conditions (dashed line): 14/10-h light/dark cycle +3 -h night interruption (incandescent lights) at $22 / 18^{\circ} \mathrm{C}$. remaining plants on one side of the partition in the box using an Lshaped tool with a sharp edge drawn through the soil at a depth of $\approx 4 \mathrm{~cm}$. This sheared most roots at that depth. The cart then was placed in a vernalization chamber at $10^{\circ} \mathrm{C}$ for the allotted number of days.

Five more plants from each quadrant were sampled at the end of the vernalization treatment. Plant dry mass and leaf counts were recorded. The lengths of all leaves also were measured at this time, including those within the pseudostem. In no case was a scape observed.

Data recorded at $180 \mathrm{~d}$ included bulb fresh mass; top, bulb, and scape dry mass; mean bulb diameter at the equator (one measurement in the thickest direction and one perpendicular to the first); height; number of green leaves; proportion of plants flowering within the quadrant; and flower stage. Tissue types were bulked within a quadrant for weighing. All bulbs were examined for internal floral development; only one was found in the entire harvest. All other flowers were developed at least to the point of partially open umbel.

Regression of mean plant dry mass after vernalization treatments was performed with the SAS general linear models procedure (GLM) (SAS Institute, 1990; Table 2). Final harvest data at $180 \mathrm{~d}$ were analyzed as a split-split-plot design, also with SAS GLM. Bulb : top dry mass ratios were log-transformed before analysis.

\section{Results}

'Buffalo' grew more vigorously than 'Granex 33' and was taller and heavier at the initiation of vernalization treatments at all three leaf stages (Table 1). The tag leaf (third, fifth, or seventh leaf) in each case was longer for 'Buffalo' relative to 'Granex 33'.

Mean, total plant dry mass at the end of vernalization was regressed on days of vernalization treatment (Fig. 2). For plants treated at the third leaf stage, dry-matter accumulation was best represented by a quadratic model. As the stage of vernalization 
increased to the fifth leaf, the quadratic term became statistically nonsignificant for 'Buffalo'. For all plants vernalized at the seventh leaf stage, the best fit curve was linear. Undercutting reduced total dry mass an average of $42 \%$ for 'Buffalo' compared with $27 \%$ for 'Granex 33'.

While dry-matter accumulation was reduced substantially by undercutting (Fig. 2) and plant height decreased (data not shown), leaf initiation continued at the same rate as for non-undercut controls (Fig. 3).

Neither cultivar flowered consistently when undercut and vernalized at the third leaf stage (Fig. 4). 'Buffalo' is a bolting-resistant cultivar. The few cases $(<10 \%)$ of flowering for 'Buffalo' treated in the third- and fifth-leaf stages were considered aberrant as no flowering occurred for 'Buffalo' vernalized and undercut at the seventh leaf stage, a treatment much more conducive to flowering. 'Granex 33' responded in a consistent manner only in the fifth- and seventh-leaf stages. Therefore a second analysis of variance was performed for the proportion of flowering. Since almost no flowering occurred for 'Buffalo' or 'Granex 33' undercut and vernalized at the thirdleaf stage, data for these combinations were not included in the second reduced analysis (Table 2). For 'Granex 33', flowering increased significantly as the leaf stage at vernalization increased and the duration of cold treatment increased. Undercutting caused a pronounced decrease in flowering and an increase in the number of vernalizing days required to elicit the flowering response.

'Buffalo' plants accumulated $\approx 38 \%$ more dry matter per plant than 'Granex 33' regardless of leaf stage of vernalization or undercutting treatment (Table 3). The effect of cultivar on total dry mass per plant at the end of the 180-d growth period was highly significant (Table 2). However, the effect of the leaf stage at which vernalization was imposed was less so, and there was no obvious effect of the duration of the ver-
Table 2. F values and their statistical significance from the analysis of variance of final harvest data at $180 \mathrm{~d}$ for 'Buffalo' and 'Granex 33' onions.

\begin{tabular}{|c|c|c|c|c|}
\hline Source & $\begin{array}{l}\text { Proportion } \\
\text { flowering }\end{array}$ & $\begin{array}{l}\text { Total dry } \\
\text { mass/plant }\end{array}$ & $\begin{array}{c}\text { Fresh mass/ } \\
\text { bulb }\end{array}$ & $\begin{array}{l}\text { Bulb : top } \\
\text { ratio }^{y}\end{array}$ \\
\hline$\overline{R e p}$ & $65.8^{* *}$ & $54.4^{* *}$ & $57.7^{* *}$ & $39.5^{* *}$ \\
\hline Days $^{w}$ & $83.3^{* *}$ & 1.2 & $13.1^{* *}$ & $45.5^{* *}$ \\
\hline Stage $^{\mathrm{w}}$ & $178.9^{* *}$ & $3.4^{*}$ & $38.0^{* *}$ & $123.5^{* *}$ \\
\hline Days $\times$ stage & $16.2^{* *}$ & 0.7 & 1.0 & $3.0^{*}$ \\
\hline Error a & $7.6^{* *}$ & 1.6 & 1.4 & $2.1^{*}$ \\
\hline Undercut & $78.8^{* *}$ & $122.8^{* *}$ & $93.9^{* *}$ & $7.1^{*}$ \\
\hline Days $\times$ undercut & $14.4^{* *}$ & 0.5 & 1.7 & 0.7 \\
\hline Stage $\times$ undercut & $8.7^{*}$ & 0.9 & 3.0 & 1.5 \\
\hline Days $\times$ stage $\times$ undercut & 1.8 & 0.7 & 0.9 & 0.4 \\
\hline Error b & --- & 1.3 & 0.9 & 0.9 \\
\hline Cultivar & --- & $91.9^{* *}$ & $19.4^{* *}$ & $223.3^{* *}$ \\
\hline Days $\times$ cultivar & --- & 0.6 & 0.7 & 0.7 \\
\hline Stage $\times$ cultivar & --- & 1.1 & 1.4 & 0.4 \\
\hline Days $\times$ stage $\times$ cultivar & --- & 0.9 & 0.6 & $2.3^{*}$ \\
\hline Cultivar $\times$ undercut & --- & $5.1^{*}$ & 1.7 & 0.2 \\
\hline Days $\times$ cultivar $\times$ undercut & --- & 0.2 & 0.6 & 0.7 \\
\hline Stage $\times$ cultivar $\times$ undercut & --- & 2.1 & 1.1 & 0.5 \\
\hline Days $\times$ stage $\times$ cultivar $\times$ undercut & --- & 1.3 & 0.7 & 0.9 \\
\hline
\end{tabular}

z'Buffalo' and the third-leaf stage for 'Granex 33' were deleted from the analysis for this variable.

y Bulb : top dry-mass ratios were transformed to their log values.

${ }^{\mathrm{w}}$ Days $=$ duration of vernalizing treatment; stage $=$ third-, fifth-, or seventh-leaf stage.

${ }^{*},{ }^{* *}$ Significant at $P \leq 0.05$ or 0.0001 , respectively.

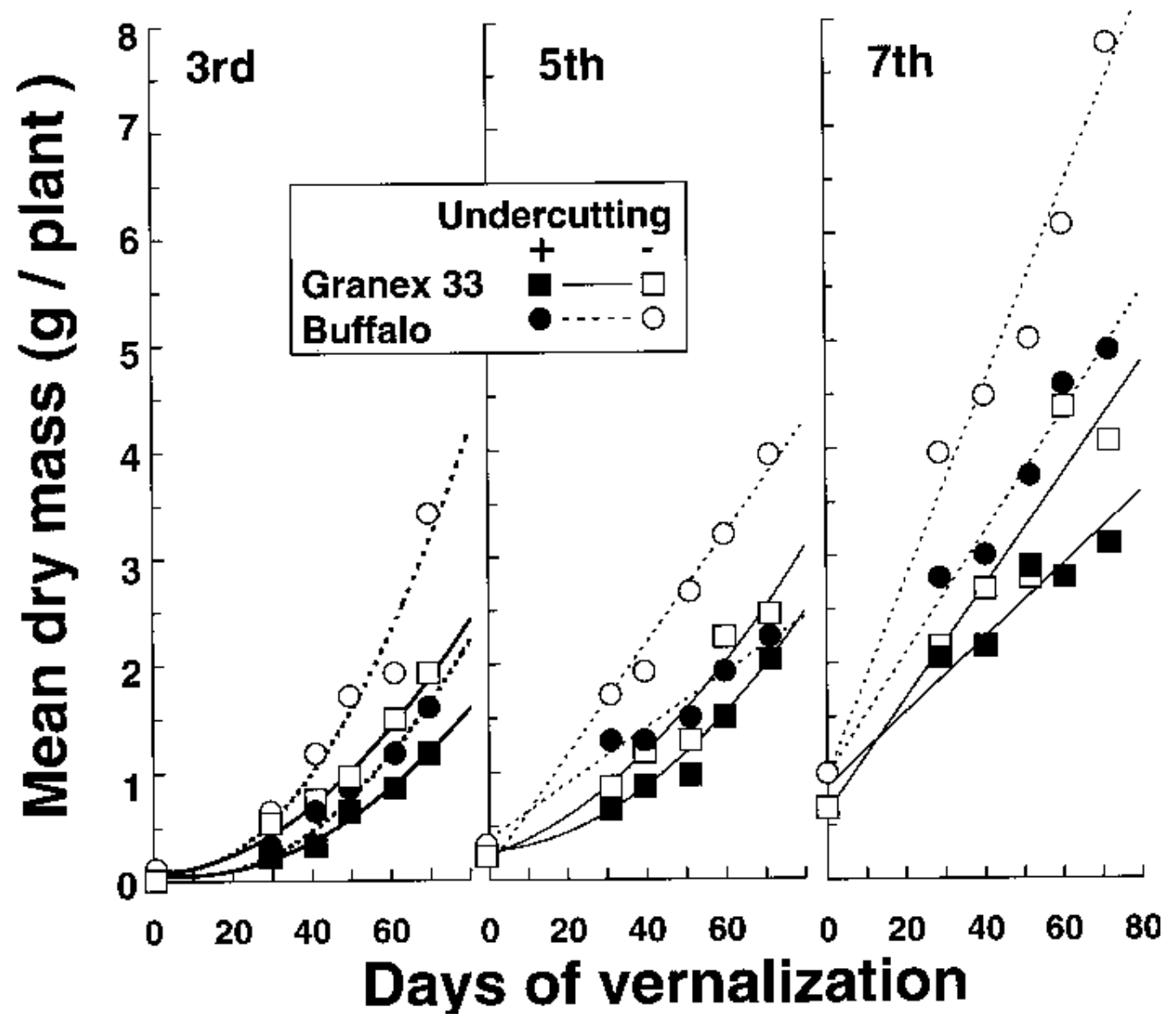

Fig. 2. Mean total plant dry mass of 'Granex 33' and 'Buffalo' onions immediately following undercutting and vernalizing treatments at the third, fifth, or seventh visible leaf stages. The first points in each curve represent the initiation of vernalizaing and undercutting treatments. 
nalization treatment. There was a decrease in final dry mass of $\approx 30 \%$ for both cultivars due to undercutting at the beginning of the vernalization treatment.

On average, fresh mass of bulbs of 'Buffalo' were $20 \%$ greater than 'Granex 33' (Fig. 5). Bulb fresh mass decreased as the leaf stage at which vernalization was imposed increased. This was true for both cultivars. Also, as the duration increased from 30 to $70 \mathrm{~d}$, bulb fresh mass decreased. Undercutting reduced fresh mass of bulbs overall $\approx 32 \%$. The main effects of treatments and cultivars
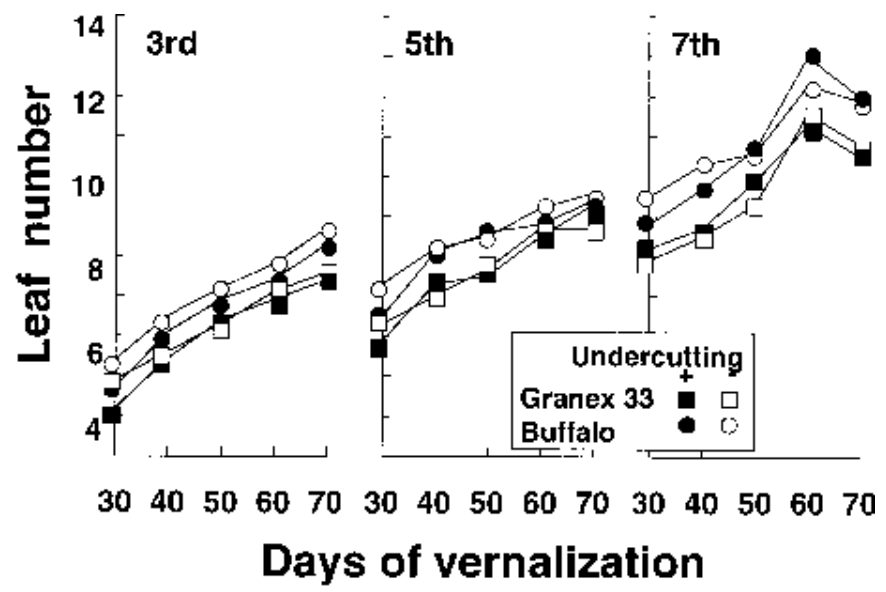

Fig. 3. Leaf number of 'Granex 33' and 'Buffalo' onions immediately following undercutting and vernalizing treatments at the third, fifth, or seventh visible leaf stages.

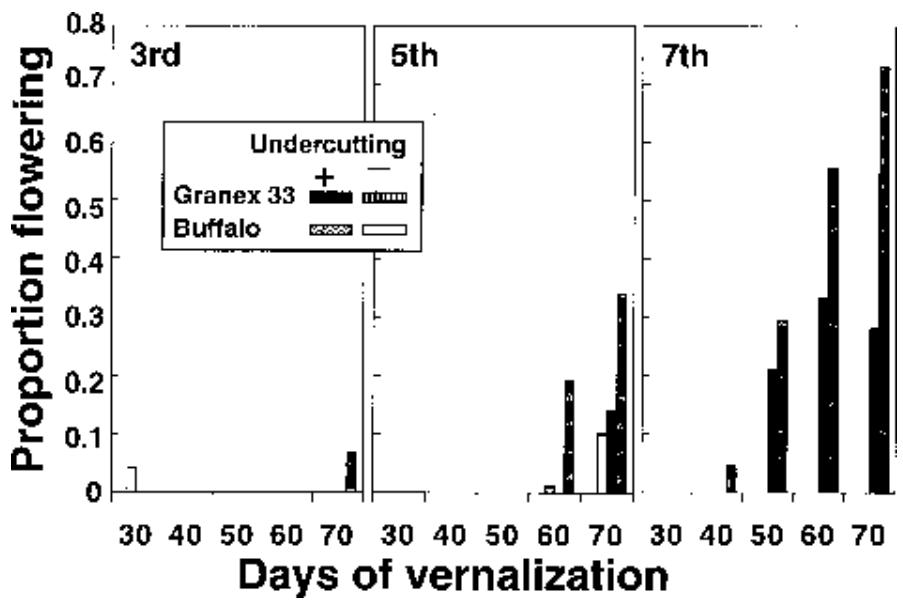

Fig. 4. Proportion of 'Granex 33' and 'Buffalo' onions that flowered by $180 \mathrm{~d}$ after undercutting and vernalization treatments at the third, fifth, or seventh visible leaf stages.

Table 3. Dry mass per plant at $180 \mathrm{~d}$ for 'Buffalo' and 'Granex 33' onions vernalized at the third-, fifth-, and seventh-leaf stages with $(+)$ and without (-) undercutting.

\begin{tabular}{lccr}
\hline \hline \multirow{2}{*}{$\begin{array}{l}\text { Leaf } \\
\text { stage }\end{array}$} & Undercutting & \multicolumn{2}{c}{ Dry mass $(\mathrm{g} / \text { plant })^{\mathrm{z}}$} \\
\cline { 3 - 4 } Third & + & $16.2 \pm 1.2^{\mathrm{y}}$ & \multicolumn{1}{c}{ Granex 33 } \\
& - & $22.6 \pm 1.3$ & $17.0 \pm 1.0$ \\
Fifth & + & $14.2 \pm 1.3$ & $12.1 \pm 1.1$ \\
& - & $21.3 \pm 1.1$ & $15.2 \pm 1.0$ \\
Seventh & + & $16.0 \pm 0.9$ & $12.4 \pm 1.4$ \\
& - & $24.5 \pm 1.8$ & $16.8 \pm 1.2$ \\
\hline
\end{tabular}

${ }^{\mathrm{z}}$ Means are across days of vernalization, 15 samples of five plants each. $\mathrm{y}_{\mathrm{SE}}$ of the mean. on bulb fresh mass were highly significant, but interaction effects were not (Table 2).

There was a higher efficiency of partitioning of dry matter to bulb growth in 'Granex 33' compared with 'Buffalo' (Fig. 6). The effect of cultivar was significant at $P \leq 0.0001$ (Table 2). The bulb : top ratio decreased as leaf stage or number of vernalizing days within leaf stage increased. Undercutting also reduced this ratio, especially for plants undercut and vernalized at the fifth-leaf stage.

These data represent flowering and nonflowering plants, as bulbs and tops were bulked for weighing within each replicate. Bulb diameters were recorded individually, however. Since the objective was to evaluate the effectiveness of undercutting as a means of limiting losses of marketable bulbs in circumstances of probable bolting (seventh-leaf stage), mean diameters of bulbs grown on the nonflowering plants vernalized and undercut at the seventh-leaf stage were calculated separately (Table 4). Undercutting reduced diameter of harvestable bulbs by $16 \%$.

\section{Discussion}

Each phase of the onion life cycle (vegetative leaf production, floral induction, scape development, and bulbing) is related to the others but has its own temperature and photoperiod optima. Leaf growth is enhanced under short photoperiods and warm temperatures (Brewster, 1994). A strong short-day signal was used in the prevernalization and vernalization conditions in the growth chambers. While enhanced in long photoperiods, floral induction will occur at any photoperiod if temperatures are within the optimum range of 6 to $12^{\circ} \mathrm{C}$. After floral induction, scape development and bulbing are enhanced by long photoperiods. The night interruption of the dark cycle in the postvernalization phase provided a strong long-day signal. Under these conditions, temperature determines whether scape development or bulbing predominates. Temperatures near $17{ }^{\circ} \mathrm{C}$ enhance flower stalk development, while temperatures of $30{ }^{\circ} \mathrm{C}$ result in rapid bulbing, even to the point of crushing an inflorescence present within the bulb (Holdsworth and Heath, 1950).

Different cultivars have different minimum size requirements for response to the floral induction stimulus (Rabinowitch, 1990). Although there was a small amount of bolting for 'Granex 33' treated at the third visible leaf stage, its minimum size with significant (19\%) flowering was $0.25 \mathrm{~g}$ dry mass and five visible leaves vernalized for $60 \mathrm{~d}$ (Table 1 and Fig. 4). Plant undercutting at the beginning of the cold treatments decreased dry mass of both cultivars (Fig. 2). Undercutting probably decreased bolting in 'Granex 33' by delaying the achievement of the critical size required for the flowering response by 10 to $12 \mathrm{~d}$ (Fig. 2).

The critical size for the bolting-resistant cultivar Buffalo is $>1.0$ $\mathrm{g}$ dry mass and seven visible leaves vernalized for $70 \mathrm{~d}$ (Table 1).

Although plant dry matter was reduced by undercutting, leaf number was not greatly affected (Fig. 3). Leaf number has often been used as an indicator of physiological age (Rabinowitch, 1990), but our data suggest that leaf number per se does not determine sensitivity to vernalization. Other factors, such as leaf area (Holdsworth and Heath, 1950) or dry-matter content (Brewster, 1985), have been suggested. Brewster (1985) showed that lowcarbohydrate plants, as well as smaller plants, required longer vernalizing conditions to flower. In non-experimental field work, however, visible leaf number remains the simplest, practical indicator of physiological age.

Duration as well as the timing of the cold period determine the flowering response. 'Granex 33' at the third-leaf stage $(0.07 \mathrm{~g}$; Table 1) showed a small flowering response with $70 \mathrm{~d}$ at $10^{\circ} \mathrm{C}$ (Fig. 
4), and the minimum number of cold days required for flowering decreased as the plant size before vernalization increased to 0.25 $\mathrm{g}$ (fifth-leaf stage) and $0.69 \mathrm{~g}$ (seventh-leaf stage).

The lack of scapes within the pseudostem of any plants at the postvernalization harvest indicates that although floral initiation must have occurred, development of the scape was inhibited by the short 10-h photoperiod (Scully et al., 1945; Rabinowitch, 1990). After vernalization, the moderate $22 / 18{ }^{\circ} \mathrm{C}$ temperature regime plus long photoperiods permitted flower development and bulbing.

Beginning at the fifth-leaf stage, fresh mass per bulb and bulb : top dry-mass ratio decreased as leaf stage and number of vernalizing days increased for 'Granex 33' and 'Buffalo'. In the fifth- or seventh-leaf stage, 70 vernalizing days resulted in $\approx 60 \%$ reduction in bulb fresh mass due to duration of vernalization alone (Fig. 5). Crop yield and percentage bolting can be inversely related (Corgan and Kedar, 1990). However, the fact that these variables decreased for both cultivars suggests that the decrease was not a result of a competition with flower development ('Buffalo' did not flower). It is probably related to the fact that as plant stage and treatment duration increased, there were fewer long days at higher temperature remaining before harvest at $180 \mathrm{~d}$ (Fig. 1).

For 'Granex 33' plants treated in the fifth- and seventh-leaf stages, the decrease in fresh mass per bulb due to undercutting was substantial with short vernalizations but became smaller as number of vernalizing days increased (Fig. 5). All bulbs were weighed, regardless of flowering, although bulbs produced on flowering plants are unmarketable and customarily left in the field at harvest. Therefore to evaluate the effect of the undercutting on yield, it is appropriate to consider the effect of undercutting on flowering (i.e., the number of bulbs) and on bulb diameter of nonflowering plants.

From 1 Dec., a grower would expect 70 vernalizing days before spring in much of the southeastern United States. For a boltingsensitive cultivar like 'Granex 33', the loss of harvestable bulbs associated with bolting would be large - up to $73 \%$ in this study. Undercutting could reduce such loss by about half (Fig. 4). Reduction in size of the remaining bulbs due to undercutting would be smaller-about $16 \%$ in this experiment (Table 4). Thus, until a sweet, short-day onion cultivar is developed that is resistant to bolting, undercutting may provide a low-cost approach to reducing the probability of bolting in a fall-seeded crop that has made excessive growth before the cold of winter.

\section{Literature Cited}

Brewster, J.L. 1985. The influence of seedling size and carbohydrate status and of photon flux density during vernalization on inflorescence initiation in onion (Allium cepa L.). Ann. Bot. 55:403-414.

Brewster, J.L. 1987. Vernalization in the onion-A quantitative approach, p. 171-183. Proc. 45th Easter School Agr. Sci., Manipulation of flowering. Butterworths, London.

Brewster, J.L. 1994. Onions and other vegetable Alliums. CAB International, Wallingford, Oxon, UK.

Corgan, J.N. and N. Kedar. 1990. Onion cultivation in subtropical climates, p. 31-47. In: H.D. Rabinowitch and J.L. Brewster (eds). Onions and allied crops. vol. 2. CRC Press, Boca Raton, Fla.

Downs, R.J. and J.F. Thomas. 1991. Phytotron procedure manual. Tech. Bul.244, North Carolina State Univ., North Carolina Agr. Res. Serv., Raleigh. replicate carts.
Holdsworth, M. and O.V.S. Heath. 1950. Studies in the physiology of the onion plant. IV. The influence of day-length and temperature on the flowering of the onion plant. J. Expt. Bot. 1:353-375.

Rabinowitch, H.D. 1990. Physiology of flowering, p. 113-134. In: H.D. Rabinowitch and J.L. Brewster (eds). Onions and allied crops. vol. 1. CRC Press, Boca Raton, Fla.

SAS Institute. 1990. SAS/STAT user's guide, version 6, 4th ed. vol. 2, GLM-VARCOMP. SAS Inst., Cary, N.C.

Scully, N.J., M.W. Parker, and H.A. Borthwick. 1945. Interaction of nitrogen nutrition and photoperiod as expressed in bulbing and flowerstalk development of onion. Bot. Gaz. 107:52-61.

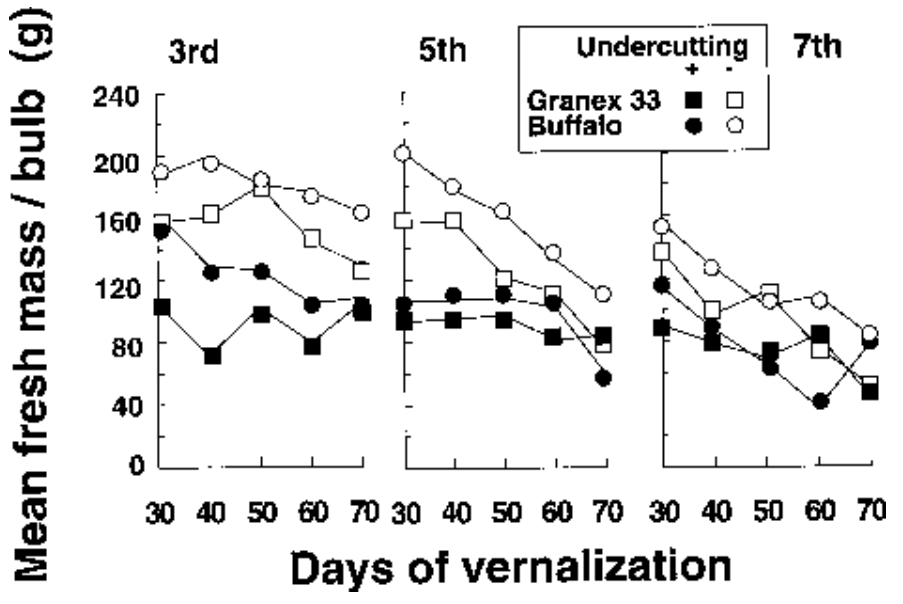

Fig. 5. Mean fresh mass per bulb at $180 \mathrm{~d}$ for 'Granex 33' and 'Buffalo' onions after undercutting and vernalization treatments at the third, fifth, or seventh visible leaf stages.

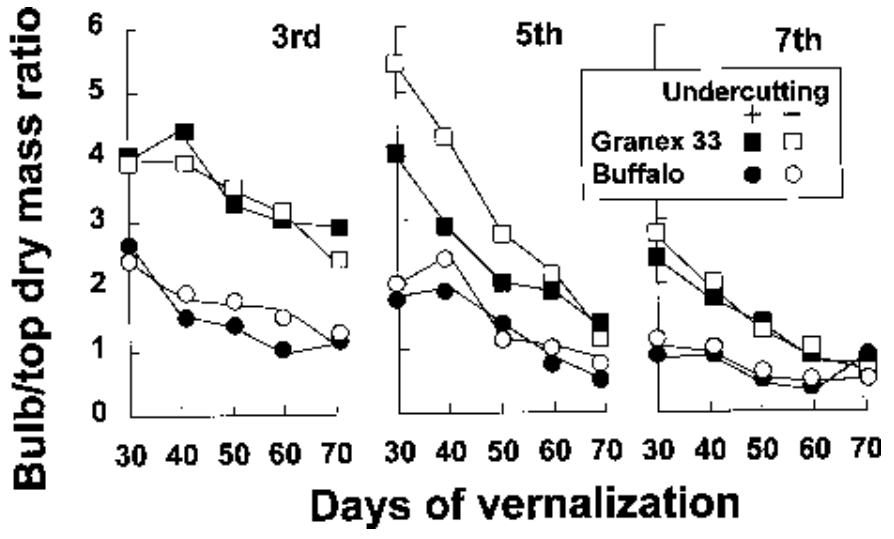

Fig. 6. Bulb : top dry-mass ratio at $180 \mathrm{~d}$ for 'Granex 33' and 'Buffalo' onions after undercutting and vernalization treatments at the third, fifth, or seventh visible leaf stages.

Table 4. Effect of undercutting on bulb diameter of nonflowering 'Buffalo' and 'Granex 33' onion plants vernalized at the seventh-leaf stage.

\begin{tabular}{|c|c|c|c|c|c|c|}
\hline \multirow[b]{3}{*}{ Cultivar } & \multirow[b]{3}{*}{ Undercut } & \multicolumn{5}{|c|}{$\operatorname{Diam}(\mathrm{mm})^{\mathrm{z}}$} \\
\hline & & \multicolumn{5}{|c|}{ No. vernalizing days } \\
\hline & & 30 & 40 & 50 & 60 & 70 \\
\hline \multirow[t]{2}{*}{ Buffalo } & - & $64.3 \pm 12(15)$ & $56.1 \pm 16(15)$ & $49.9 \pm 15(15)$ & $52.6 \pm 12(15)$ & $48.9 \pm 11(15)$ \\
\hline & + & $55.7 \pm 14(15)$ & $49.4 \pm 20(14)$ & $40.1 \pm 16(15)$ & $33.9 \pm 12(14)$ & $45.5 \pm 10(15)$ \\
\hline \multirow[t]{2}{*}{ Granex 33} & - & $67.0 \pm 9(15)$ & $59.3 \pm 12(15)$ & $64.3 \pm 9(12)$ & $56.9 \pm 11(8)$ & $55.6 \pm 7(5)$ \\
\hline & + & $58.5 \pm 9(15)$ & $54.4 \pm 9(16)$ & $48.3 \pm 12(13)$ & $38.2 \pm 18(11)$ & $47.2 \pm 6(12)$ \\
\hline
\end{tabular}

$\overline{\mathrm{z}}$ Mean $\pm \mathrm{SD} ; \mathrm{n}$ (in parentheses) $=$ number of individual plants remaining without flowers, pooled from all three 